\title{
Erratum to: Development of fetal brain sulci and gyri: assessment through two and three-dimensional ultrasound and magnetic resonance imaging
}

\author{
Liliam Cristine Rolo • Edward Araujo Júnior •
}

Luciano Marcondes Machado Nardozza • Patrícia Soares de Oliveira •

Sérgio Aron Ajzen • Antonio Fernandes Moron

Published online: 27 October 2010

(C) Springer-Verlag 2010

\section{Erratum to: Arch Gynecol Obstet}

DOI 10.1007/s00404-010-1691-y

One of the author's surname was incorrect in the online published article. The correct surname is Araujo Júnior.

The correct author group should be Liliam Cristine Rolo, Edward Araujo Júnior, Luciano Marcondes Machado Nardozza, Patrícia Soares de Oliveira, Sérgio Aron Ajzen, Antonio Fernandes Moron

The online version of the original article can be found under doi:10.1007/s00404-010-1691-y.

L. C. Rolo · E. Araujo Júnior $(\varangle) \cdot$ L. M. M. Nardozza •

A. F. Moron

Department of Obstetrics, São Paulo Federal University

(UNIFESP), Rua Carlos Weber, 950 apto. 113 Visage,

Alto da Lapa, São Paulo, SP, Brazil

e-mail: araujojred@terra.com.br

P. S. de Oliveira · S. A. Ajzen

Department of Diagnostic Imaging, São Paulo Federal

University (UNIFESP), São Paulo, SP, Brazil 